\title{
GLATIRAMER ACETATE TREATMENT-RELATED EFFECTS ON VISUAL EPS AND P300 WAVE IN PATIENTS SUFFERING FROM MULTIPLE SCLEROSIS
}

\author{
Received November 30, 2012.
}

\begin{abstract}
Multiple sclerosis is an inflammatory neurological disease of young adults that leads to numerous therapeutic problems and to severe disability. Glatiramer acetate (GA) is a diseasemodifying drug used frequently for long-term treatment of the disease. We investigated the impact of GA treatment on the parameters of reversal-pattern visual evoked potentials and event-related P300 wave (reflecting visual acuity and cognitive dysfunction). Relapsingremitting multiple sclerosis patients either subjected to one-year-long continuous treatment with GA or without any disease-modifying therapy and also healthy controls were involved in the study. The above-mentioned parameters were analyzed at two time points, at the first recording and after one year. It was found that GA did not exert a significant influence on the phenomena studied at least during the one-year follow-up. This finding is in contrast to most of the clinical observations.
\end{abstract}

Keywords: multiple sclerosis, visual evoked potentials, P300 wave, glatiramer acetate.

\section{INTRODUCTION}

Multiple sclerosis (MS) is one of the most debilitating inflammatory neurological diseases of young adults. Patients gradually lose their ability to deal with common daily activities; as an end-point, they become totally dependent and, sadly, a burden to society. From this viewpoint, an early proper diagnosis of the disease is mandatory in order to delay, as long as possible, major disability. A valuable tool in fulfilling this task is testing evoked potentials (EPs). Introduced into practice in the 1950s, some of these neurophysiological methods constitute a useful diagnostic and prognostic tool.

One can define EPs as EEG-derived responses of the CNS to external stimuli. Stimuli are differentiated, according to the involved sensory system, visual, auditory, or somatosensory. The EPs recorded over different body regions are classified as near-field or

\footnotetext{
${ }^{1}$ Pharmacology Department of the University of Medicine and Pharmacy "Iuliu Hațieganu," Cluj-Napoca, Romania.

${ }^{2}$ Neurology Department of the University of Medicine and Pharmacy "Iuliu Haţieganu," Cluj-Napoca, Romania.

Correspondence should be addressed to Z. Z. Major

(e-mail: zoltan.major@umfcluj.ro).
}

far-field potentials, according to the distance of the neural generator from the recording place. Another classification involves as a criterion the cognitive participation of the subject; if present, we refer to it as event-related potentials (ERPs), if not, then as stimulus-related evoked potentials (EPs). We have used both categories, visual EPs (VEPs), as stimulusrelated, and the P300 wave as an ERP.

Through demyelination, MS affects the conductivity in the CNS, this being mirrored by the EP latencies. When nerve fibers are affected, amplitude changes can also be assumed. The disease starts quite frequently under the form of a clinically isolated syndrome, with visual symptoms in most cases. For this reason, VEP recording might be helpful, revealing pathological findings even under circumstances when the sensitivity of imaging techniques is not enough. As the disease progresses and the extent of tissue loss becomes important, a variable degree of cognitive dysfunction might install. A feasible approach to characterize the effect is theoretically the P300 wave, an objective measure for certain cognitive processes.

Visual EPs are the most commonly used evoked brain responses among the diagnostic procedures for MS. When retrobulbar optical neuropathy is present 
(as the basis of a clinically isolated syndrome or a relapse), VEPs are impaired. These changes are either prolongation of the latency (a part of the revised McDonald criteria [1]), or decrease in the amplitude [2], or even changes in the component morphology [3].

A key issue when assessing the efficacy of a disease-modifying drug is to find objective measures of the corresponding pharmacological effect. Recording of VEPs were proposed for this. According to a study using interferon beta-1a for MS treatment, there was no impact observed on these potentials [4], while other researchers reported significant changes [5]. Natalizumab showed an even better profile observed after one year of treatment, this was ameliorating the electrophysiological parameters of VEPs, somatosensory EPs, and motor EPs [6]. For a drug used in the treatment of MS, such as glatiramer acetate (GA), the available data are poor and indirect [7], and this explains the need to evaluate GA's impact on VEPs.

Event-related potentials, similarly to other EPs, are conditioned for normality by the integrity of conduction in the CNS; the state of the white matter is crucially important. Even the smallest degree of demyelination can influence the conductance in the CNS, causing, at least theoretically, different degrees of cognitive dysfunction. According to the initial viewpoint, the cognitive EPs allow us to identify even the slightest changes before relevant results of standard neuropsychological tests [8].

The P300 (P3) is a positive EEG-derived (also by the averaging technique) deflection observed approximately $300 \mathrm{msec}$ after triggering; it can be elicited by either visual, auditory, or somatosensory stimuli. It includes two main components, P3a and P3b, which are not always identifiable separately. These are waves corresponding to the main supposed generators, the dopaminergic frontal and noradrenergic temporal ones [9]. The investigated parameters of P300 usually are the latencies; the amplitudes are characterized by high inter- and intrapersonal variability.

Latency changes of P300 in MS were reported in the literature (prolongation when compared with normal $[10,11])$, and the test was even used for evaluation of evolution of the disease and response to therapy $[12,13]$. The wave was even investigated as a tool to predict treatment responses to a symptomatic approach with modafinil and found to show such a role [14]. The P300 test was proposed recently as an objective method for evaluation of cognitive dysfunction also for pediatric patients [15].

As was mentioned above, we have only indirect data with respect to ERPs in the case of GA [14]. There is only one prospective study stating a positive effect of a one-year-long interferon beta- $1 \mathrm{~b}$ treatment on the P300 parameters in MS patients [16]. Considering these, we have tried to evaluate the effects of GA treatment on VEPs and cognitive ERPs (P300).

\section{METHODS}

Our study was performed on relapsing-remitting multiple sclerosis (RRMS) patients admitted to the Neurology Clinic of the Cluj County Emergency Hospital (Romania).

The impact of GA treatment on the parameters of two EEG phenomena, the reversal-pattern VEPs and event-related P300 wave (reflecting visual acuity and cognitive dysfunction), was investigated in three groups of participants. Group 1 (hereafter, GA-treated, $n=21)$ consisted of patients with RRMS diagnosis.

TABLE 1. Examined Groups 1-3 Consisted of Relapsing-Remitting Multiple Sclerosis (RRMS) Patients and Healthy Individuals (Control)

Т а б л и ц я 1. Досліджені групи 1-3, сформовані з пацієнтів, які страждали від розсіяного склерозу, та здорових суб'єктів (контроль)

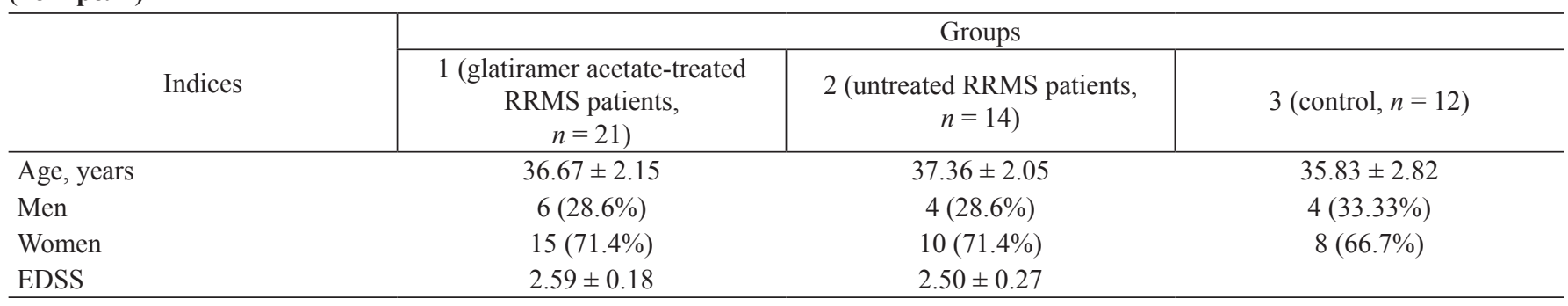

Footnote. Means \pm s.d. are shown. 
The above-mentioned parameters were analyzed at inclusion (when the first recording took place) and after one year of continuous treatment with GA (20 mg per day, subcutaneous daily injections); these time points of the analysis are designated below as time points I and II, respectively. Group 2 (hereafter, untreated, $n=14$ ) also included RRMS patients examined at inclusion in the study (time point I of examination) and after one year but without any disease-modifying treatment (time point II). Group 3 (control, $n=12$ ) was composed of healthy individuals (with only one evaluation of the investigated parameters).

Patients with mental retardation, diabetes mellitus, dyselectrolytemias, and psychiatric comorbidities were not included in the tested groups, and the presence of any sight or hearing disturbance was also an exclusion criterion.

Age was comparable in the groups; as for the sex of the participants, the distribution was identical for both RRMS groups (GA-treated and untreated) and somewhat different for the controls. Another key parameter for two former groups was the EDSS score at inclusion, which showed no statistical differences at the beginning of the study (Table 1).

After groups had been formed, evaluation started using reversal-pattern VEP and auditory-induced P300 recordings. A Medtronic Keypoint 4 device (Medtronic-Dantec, Denmark) was used to trigger and record VEPs, with $12 \times 16$ sized checkers, using a resolution of $30 \mathrm{msec}, 20 \mu \mathrm{V}$ per division, low-pass filter at $1 \mathrm{~Hz}$, high-pass filter at $0.2 \mathrm{kHz}$, maximum tolerated impedance of recording electrodes $5 \mathrm{k} \Omega$, and stimulation frequency $1 \mathrm{sec}^{-1}$. An active electrode was placed in $\mathrm{Oz}$, a reference in $\mathrm{Fz}$, and a grounding one in $\mathrm{Cz}$, according to the 10-20 system. Each eye was stimulated twice, with an average of 50 stimuli. The latency and amplitude of the N75, P100, and N135 components were measured; waveforms were also compared.

The same device was also used to record the P300 wave. Acoustic stimuli were presented through earphones according to the oddball paradigm, using a resolution of $100 \mathrm{msec}, 50 \mu \mathrm{V}$ per division, low-pass frequency at $0.2 \mathrm{~Hz}$, high-pass at $0.1 \mathrm{kHz}$, maximum tolerated impedance of the electrodes $1 \mathrm{k} \Omega$, variable stimulation frequency between 0.3 and $1 \mathrm{sec}^{-1}$, percentage of the odd stimuli $15 \%$, frequency of these stimuli $2,000 \mathrm{~Hz}$, and that of frequent ones $1,000 \mathrm{~Hz}$. Recordings were made with electrodes placed in $\mathrm{Fz}$, $\mathrm{Cz}$, and $\mathrm{Pz}$ of the 10-20 system; reference electrodes were positioned in A1 and A2, and a grounding one in Fpz. The percentage of hits and number of false hits were recorded using a neurofeedback setting; the reaction time was also recorded. Two evaluations were performed for each subject, with a total of 150 averages and 22-23 odd sounds/evaluation. The recorded parameters were the latency and amplitude of P300, the percentage of hits, number of false hits, and reaction time.

Statistical analysis was performed using Microsoft Excel, SPSS 17, and Statistica 4.5 software. After calculation of means and s.e., the paired $t$-test and variance analysis (ANOVA) were used, followed by post-hoc analysis, with the Scheffé or Dunnett T3 test, depending on the variance equality. For other circumstances, when parametric testing was not allowed, nonparametric tests were chosen (such as Wilcoxon, Mann-Whitney U, and Kruskal-Wallis). For multiple comparisons, log-linear analysis was used. The threshold $P$ value for significance for each test was $P<0.05$.

\section{RESULTS}

VEP Testing. First, it should be mentioned that normal and $\mathrm{W}$-shaped VEP waveforms were observed in groups 1 and 2 of RRMS patients (Fig. 1).

Raw data were tested first using the KolmogorovSmirnov test (all groups demonstrated normal distributions; not shown). Still, considering the small number of participants, both parametric and nonparametric tests were performed.

Statistical analysis began with the evaluation of the obtained latencies. We measured differences between the left and right latencies of the VEP components for RRMS patients and found that some asymmetry might be present, but its degree was quite comparable in all three groups (GA-treated, untreated, and control; not shown). There were no significant differences after the one-year follow-up in the individual groups.

The next aspect was to check if significant changes appeared between the groups compared with the parameters of the control group. Variance analysis and the Levene test for the homogeneity of variances were used, and it was found that equal variances could not be assumed. Therefore, we applied ANOVA and post-hoc analysis with the Dunnett T3 test doubled by their nonparametric equivalences, the KruskalWallis and Mann-Whitney U tests (taking into account the small number of patients/controls; Fig. 2). As 
$A$

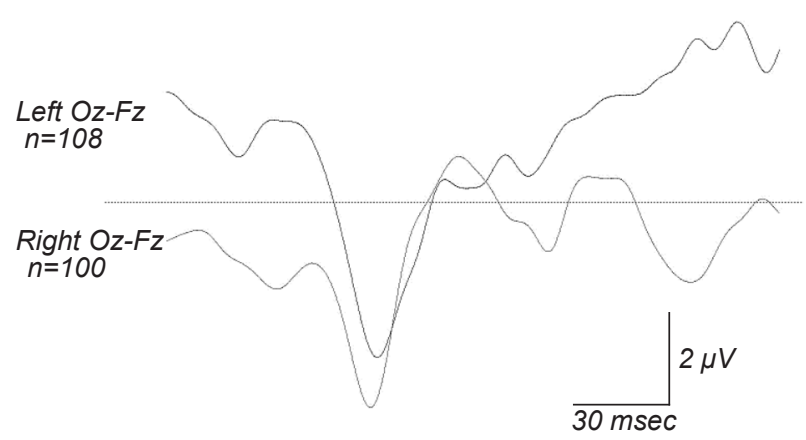

$B$

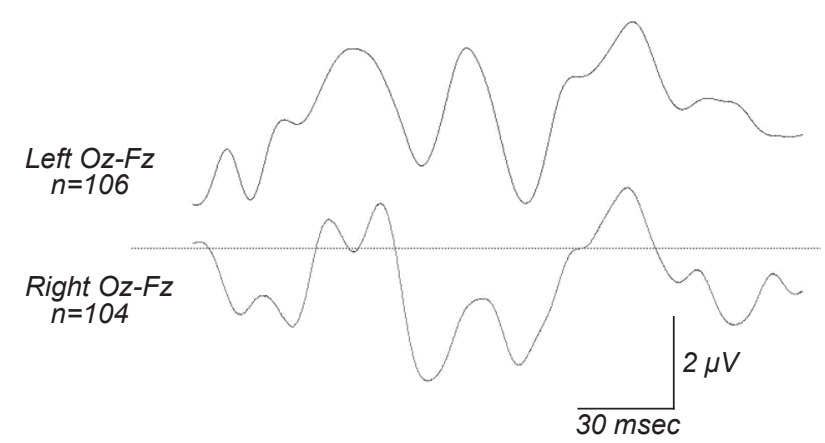

F i g. 1. Examples of visual evoked potentials observed in patients of groups 1 and 2; normal (A) and W-shaped (B) P100 waveforms are shown.

P и с. 1. Приклади зорових викликаних потенціалів, спостережуваних у пацієнтів груп 1 та 2; показано нормальні та W-подібні форми хвилі потенціалу Р100 ( $A$ та $B$ відповідно).

this diagram demonstrates, the latencies of all VEP components in both RRMS groups were significantly longer, as compared with those in healthy controls, independently of the time points of the analysis. At the same time, there were no significant differences between the GA-treated (after one-year-long treatment with GA) and untreated groups.

The next step was to check the variation in the amplitudes of VEP components using the same paradigm. The Kolmogorov-Smirnov test proved the normality of the groups for this parameter also. Then, descriptive statistics and asymmetry testing were performed; changes in the treated group and differences after one year of therapy were detected for components P100 and N135. Similar significant changes were found also for N75 after one year in the untreated group. Another noticeable difference was the amplitude reduction on both sides in the N75

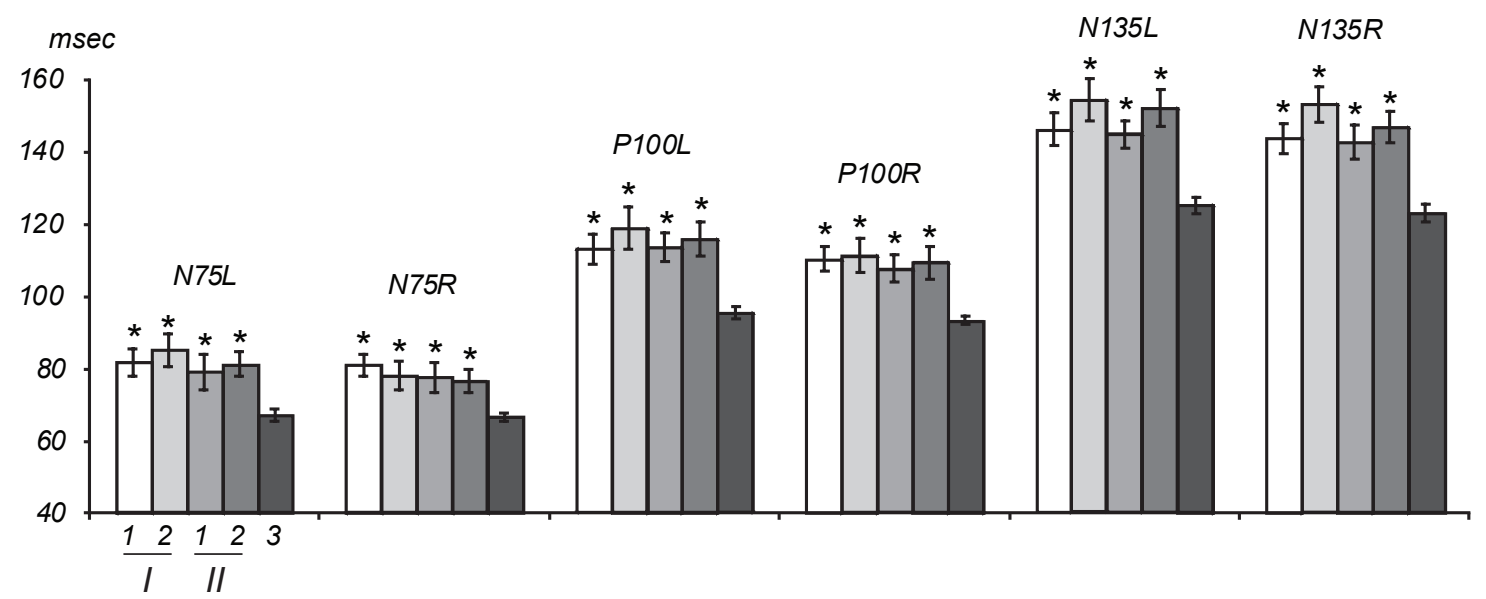

F i g. 2. Mean latencies of the components of the visual EP in relapsing-remitting multiple sclerosis (RRMS) patients treated with glatiramer acetate, GA, in time points I and II of the analysis, i.e., at the first recording and after one year of continuous treatment with GA (1), in untreated RRMS patients in time points I and II, i.e., at the first recording and after one year (2), and in healthy individuals (control, 3). * Significant difference from the control.

Р и с. 2. Середні величини латентних періодів компонентів зорових ВП у пацієнтів із розсіяним склерозом (РС), котрі проходили лікувальний курс із застосуванням глатирамеру ацетату (ГА), у моменти часу I і II, тобто під час першої реєстрації та за рік безперервного лікування (1), у пацієнтів із РC, котрі не отримували лікування, у моменти часу I і II, тобто під час першої реєстрації та за рік (2) та у здорових людей (контроль, 3). 
TABLE 2. Crosstab of the Frequencies of Relapsing-Remitting Multiple Sclerosis Patients Treated with Glatiramer Acetate (GA) and Untreated Patients (UT) According to the Treatment Status, Time Points I and II of Examination, and Morphology of the Visual Evoked Potentials, and also the Analysis of the Models Containing Principal Effects and Interactions

Т а б л и ц я 2. Перехресна таблиця частотності паціснтів, котрі страждали від розсіяного склерозу (РС), після лікування із застосуванням глатирамеру ацетату (ГА) та паціснтів з РС, які не приймали ГА згідно зі статусом лікування, моментів часу I і II у перебігу обстеження та морфології зорових викликаних потенціалів, а також аналіз моделей, що містять у собі основні ефекти та взаємодії

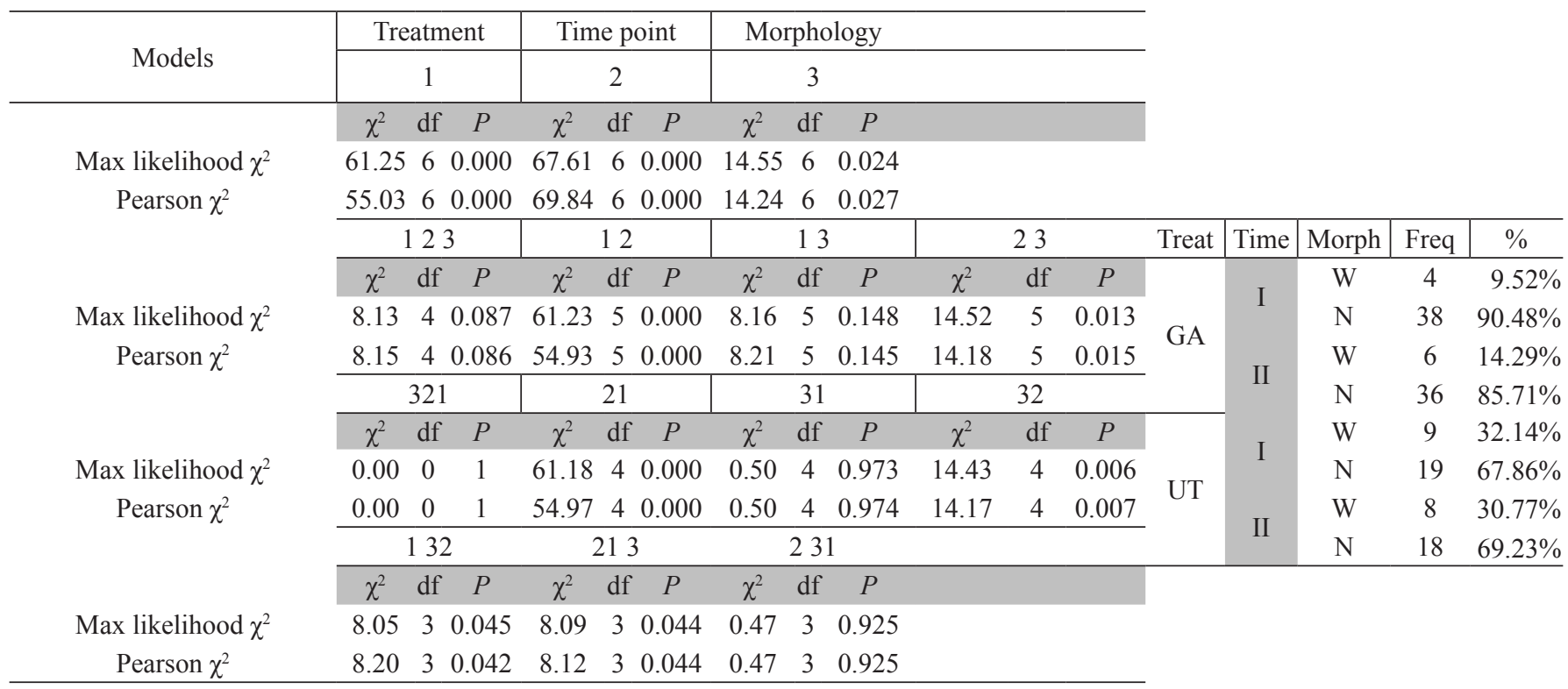

component after one year of treatment.

The intragroup analysis was followed by the intergroup comparison, using the same tests as for the latencies (Fig. 3).

The morphology of the VEPs was tested using loglinear analysis. The crosstab used and the results are shown in Table 2.

Observing the frequencies, one can notice the differences at inclusion in the study between the GA-treated and untreated groups. Because VEP morphology was not a selection criterion, different frequencies were found at the start of the study. Evaluation continued for one year; so, the initial data had no impact on the treatment-induced variability. For each principal effect (treatment, time point, and morphology), the observed frequencies differed from the expected values. As a result, the three-dimensional frequency analysis revealed a model with high adequation of the observed and anticipated frequencies in the case of association of the principal effect of time point (at inclusion $v s$ one-year follow-up), and the interaction between treatment and morphology.
The latter interaction fits the model with even higher adequation, but it is bi-dimensional.

The most constant effect was given by the moment of examination; the impact of GA treatment over the frequency of the W-like morphology is significant, the latter index being increased.

P300 Testing. After raw data related to the P300 were recorded, we proceeded as with the VEP parameters: every group was tested for normality with the help of the Kolmogorov-Smirnov test, and the distributions were found to be normal. Then, descriptive statistics were performed, and the latency values in the two time points were tested within groups (not shown). There was a significant increase in the latency values in the case of the GA-treated group during the investigated period. For the intergroup comparison, there was only one significant difference; when the starting values in the GA-treated group were compared with the control, slightly smaller values were observed, but the difference disappeared during the one-year-long treatment. In this case, we used the Scheffé test for post-hoc analysis, since the Levene 


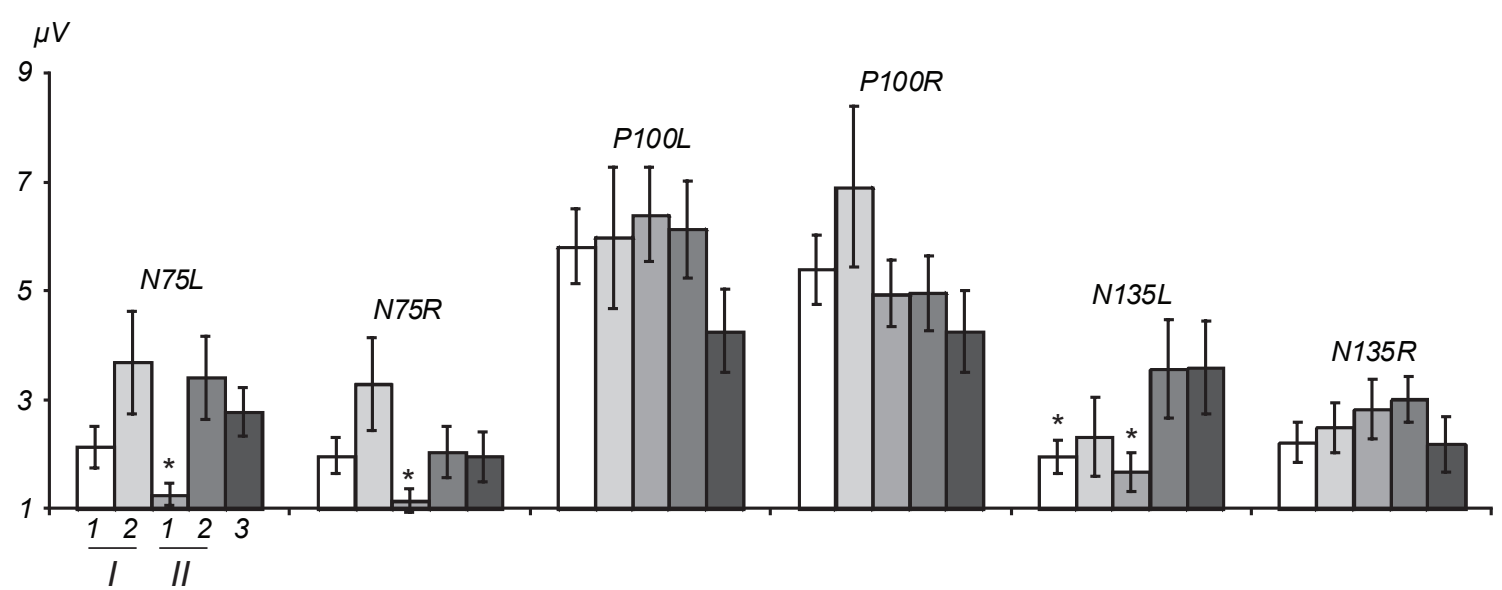

F i g. 3. Mean amplitudes of the components of visual evoked potentials in the three examined groups. Designations are the same as in Fig. 2.

Р и с. 3. Середні величини амплітуд компонентів зорового ВП у трьох обстежених групах.

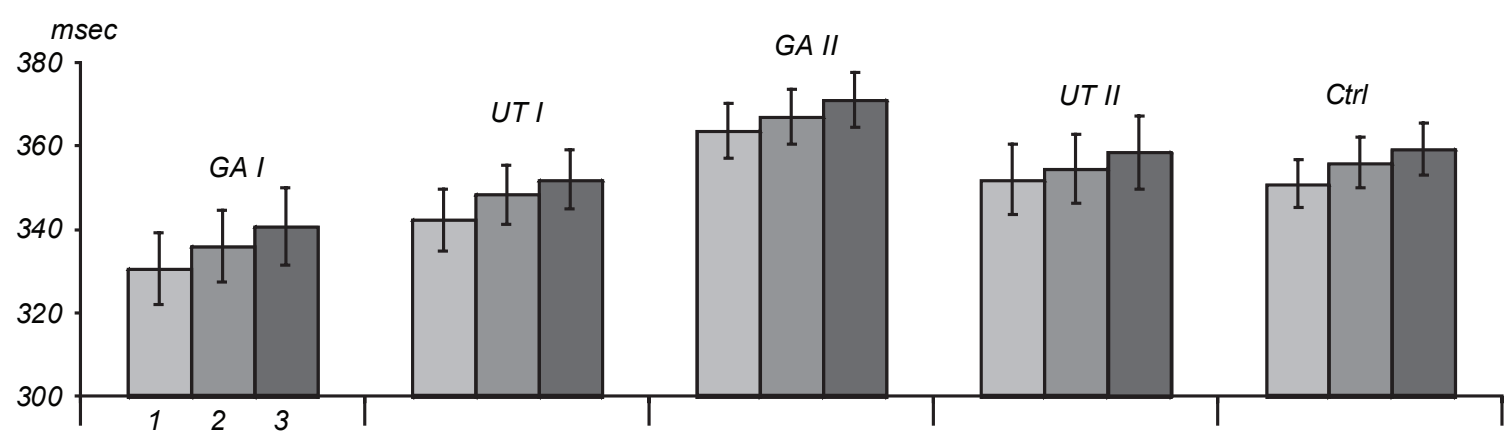

F i g. 4. P300 latencies in relapsing-remitting multiple sclerosis (RRMS) patients treated with glatiramer acetate (GA) in time points I and II of examination, i.e., at the first recording and after one year of continuous treatment with GA, GAI and GAII, respectively), in untreated RRMS patients in time points I and II, i.e., at the first recording and after one year, UTI and UTII), and in control healthy individuals (Ctrl.); 1-3 correspond to $\mathrm{Fz}, \mathrm{Cz}$, and $\mathrm{Pz}$ recordings, respectively.

P и с. 4. Латентні періоди потенціалу Р300 у пацієнтів із розсіяним склерозом (РС), котрі проходили лікувальний курс із застосуванням глатирамеру ацетату (ГА) у моменти часу I і II, тобто під час першої реєстрації та за рік безперервного лікування, GAI та GAII відповідно, у пацієнтів із PC, котрі не отримували лікування, у моменти часу I та II, тобто під час першої реєстрації та за рік, UTI та UTII відповідно), та у здорових людей (контроль); 1-3 відповідають локусам відведення Fz, Cz, та Pz.

test proved that variances were comparable (the Sheffé test being more robust than the Dunnett test) (Fig. 4).

In the GA-treated group, the P300 amplitude showed a significant increase for the $\mathrm{Cz}$ and $\mathrm{Pz}$ recordings and a marginally significant shift for Fz after one-year-long therapy. In the untreated group, no such change was detectable, although a trend toward an increase was noticeable. Since normal distribution was the case for the amplitudes too and the variances were comparable, an ANOVA-Scheffé combination was used, doubled with the nonparametric analogs. Slight differences were detected for the $\mathrm{Pz}$ recording in the case of GAtreated group $v s$ controls. More interestingly, after the one-year follow-up, both RRMS groups demonstrated significantly higher amplitudes for Fz recordings than the control, still without significant differences between them (Fig. 5).

In the case of neurofeedback parameters (hits, false hits, and reaction time), the Kolmogorov-Smirnov test proved that the distribution was not normal for some of the measures. As a consequence, we decided to use nonparametric tests (Kruskal-Wallis and MannWhitney U), since the Wilcoxon test criteria were also not satisfactory due to the lack of correspondence. No significant changes were detected for the investigated measures, although it was noticeable that, after oneyear-long GA treatment, both the percentage of hits and the reaction time became better, but only with 


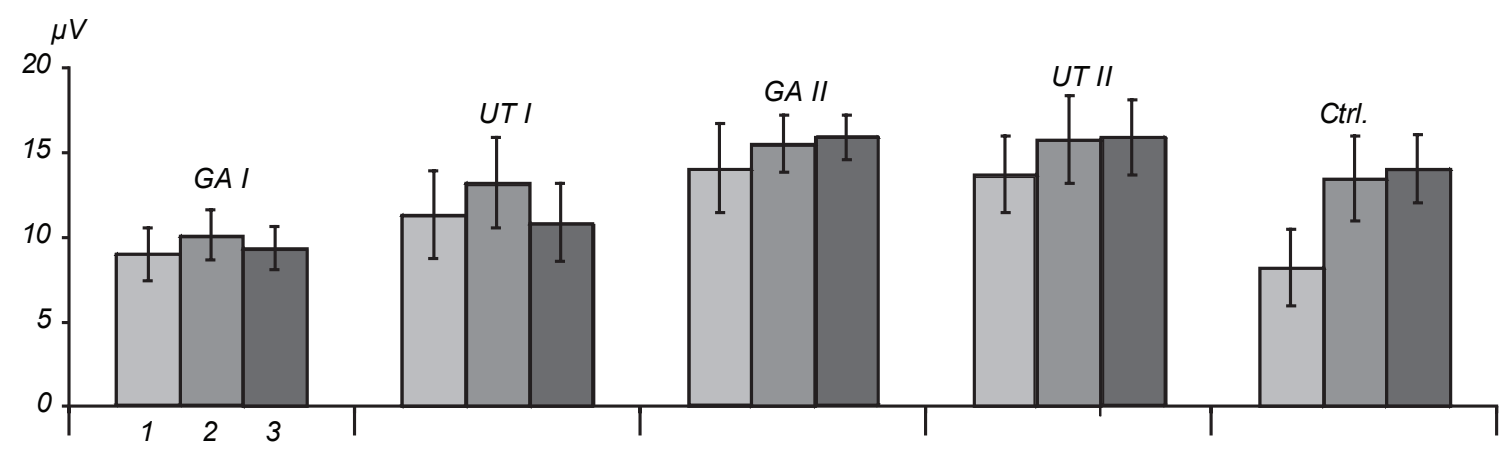

F i g. 5. P300 amplitudes in the three examined groups. Designations are the same as in Fig. 4.

Р и с. 5. Значення амплітуди потенціалу Р300 у трьох обстежених групах.

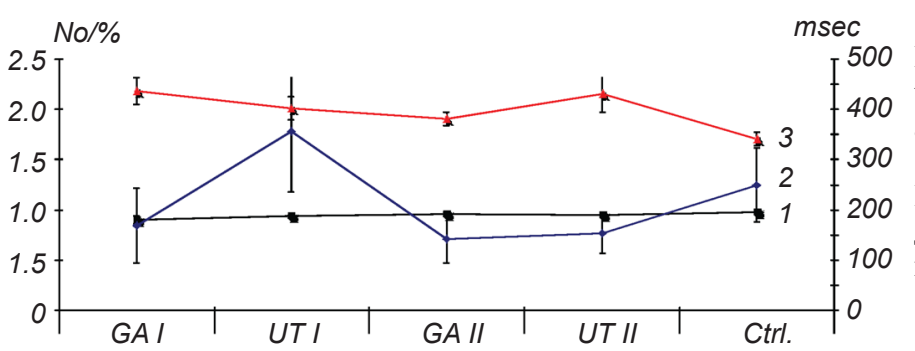

a marginal significance. When comparing the three examined groups, the reaction time showed significant increases in the case of the RRMS groups during the first recording (Fig. 6).

\section{DISCUSSION}

Evoked-potential techniques were applied in MS diagnosis together with imagery, being a useful, complementary, and objective measure oriented toward the state of the function and the loss of it. From this aspect, there is a wide consensus [1], at least regarding the VEPs. Our findings enhance a series of studies that led to the use of EPs for the diagnosis of MS. The latencies of the most important components, the N75, P100, and N135 waves, increase in the case of all MS patients, regardless of the therapeutic status, when compared with the control (in accordance with the literature, both at the beginning and at the end of the study). A one-year-long treatment with the diseasemodifying drug showed no significant beneficial effect from this viewpoint, and there were no noticeable symmetry differences between groups.

The VEP amplitudes showed increased variability, otherwise true for all evoked responses, being proportional to the section of the conductive tracts and influenced by a multitude of factors, such as bone thickness, fatty tissue presence [17], alpha rhythm dominance, oxygenation response to visual stimuli, etc. [18]. As a consequence, at least in the past, amplitudes were neglected in evaluation of EPs. Still, for visual responses, they have relevance, at least in acute and subacute phases of retrobulbar neuropathy, when an amplitude reduction is present [19]. This reduction, combined with the usually unilateral presence of retrobulbar optical neuropathy, lends support to our findings [2] (overall, significant partial asymmetry of the amplitudes for the N75 component in the RRMS groups vs control). As a consequence, we observe that the latency asymmetry recovers more rapidly than the amplitude in the case of VEPs (remyelination $v s$ axonal loss, but without a quantifiable influence of the applied treatment).

An intriguing aspect is the VEP morphology. The normal aspect, one marked positive deflection, the P100 wave, is sometimes bifid, forming either a doubled wave if the interpeak latency difference is under $10 \mathrm{msec}$, or a $\mathrm{W}$-shaped one (the same difference being between 10-50 msec), or individual waves, even more than two, when the difference is longer than $50 \mathrm{msec}$. The $\mathrm{W}$ shape appears in an increased 
proportion in MS patients [20]. This was observed $v s$ control in our study too, in accordance with the literature [21]. A one-year-long treatment with GA seems, quite interestingly, to increase the occurrence of the mentioned morphology when compared with untreated MS patients. We are lacking a feasible explanation with respect to this point; we can only suppose that GA might enhance the occurrence of oscillatory responses, probably by inducing a functioncompensating mechanism. These changes, like the gamma oscillatory response [22], can distort the VEP, causing the abnormal waveform.

The P300 component of the auditory cognitive EP was investigated in order to evaluate if cognitive dysfunction is detectable by the method. The technique has not enjoyed a wide clinical use but was used/ implemented already in other conditions also, such as dementia [23], ADHD, and/or epilepsy [24], etc. Our subjects were at the initial stage of the disease (as the EDSS score showed), and it can be assumed that cognitive changes were slight, if existent. The situation is reflected also by the considerably reduced latency values when compared with the control (in contradiction, at least for now, with the literature [10]). After one year of treatment with GA, an increase in the latency was noticed (with an obscure significance), contrasting with the untreated group and accompanied by an increase in the amplitudes. We can only hypothesize that a compensatory effect was induced during the GA treatment, either by the drug or by an intrinsic mechanism. On the one hand, the number of recruited pathways required for the response generation increases, and, due to this, the amplitude increases. On the other hand, the latency prolongation suggests that the treatment exerts a week influence on the process of remyelination (probably due to the relatively short period of evaluation, as opposed to the literature [25]).

Neurofeedback settings are represented by the cognitive tasks and the resulting parameters, when eliciting the auditory P300 using the oddball paradigm. Multiple sclerosis patients demonstrate an increased reaction time, which is used as a measure of the information processing rate [26]. Under these circumstances, our data suggest some beneficial effect of GA treatment in clinical terms; the reaction time is somewhat reduced, compared with the initial values, and the number of hits increased (despite only with marginal significance), which might increase with an increased number of cases.
The limits of our study are the following. The performed neurophysiological tests delivered an impressive amount of data, which, combined with the doubled statistical analysis, hopefully neutralized one of the limits of our study, namely participationinduced variability and the relatively small group sizes. Another concern is the duration of treatment. In order to establish whether a one-year-long followup permits or not a proper validation of all potential effects of GA in MS, further investigations are needed.

Thus, the VEP latencies in both RRMS groups are longer when compared with healthy individuals, and GA shows no impact from this aspect after one year of continuous treatment. Partial amplitude variability (N75 reduction) is noticeable in RRMS groups, compared with the control, and W-like morphology of VEPs is increased after GA treatment.

For the P300 wave, both latencies and amplitudes ( $\mathrm{Cz}$ and $\mathrm{Pz}$ recordings) increased after GA treatment. Untreated RRMS patients showed also an amplitude increase. A trend toward induction of the reaction time is noticeable after one-year-long GA treatment.

Further research is needed to evaluate if this relative lack of electrophysiological improvement is persistent even in the case where the investigation period is prolonged.

Informed consent was obtained from all persons involved in the tests.

The authors, Z. Z. Major, V. Văcăraş, A. D. Buzoianu, and D. F. Mureşanu, declare that they have no conflict of interests.

Z. Z. Major and V. Văcăraş, on the one hand, and A. D. Buzoianuand D. F. Mureşanu, on the other hand, contributed equally to the study.

Acknowledgments. This study was funded by the research grant No. 27020/44/15.11.2011 of the University of Medicine and Pharmacy "Iuliu Haţieganu," Cluj-Napoca, Romania.

We thank Crăciun Horea and Balog Carmen for their kind cooperation.

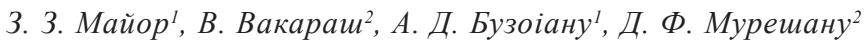

ВПЛИВ ЛІКУВАННЯ ГЛАТИРАМЕРОМ АЦЕТАТОМ НА ЗОРОВІ ВИКЛИКАНІ ПОТЕНЦІАЛИ ТА ХВИЛЮ РЗО0 У ПАЦІСНТІВ, ХВОРИХ НА РОЗСІЯНИЙ СКЛЕРОЗ

\footnotetext{
${ }^{1}$ Відділ фармакології Медичного і фармацевтичного університету „Іуліу Хат’єгану” Клуж-Напока (Румунія).

${ }^{2}$ Відділ неврології Медичного і фармацевтичного університету „Іуліу Хат'єгану” Клуж-Напока (Румунія).
} 
$\mathrm{P}$ е 3 ю м е

Розсіяний склероз - запальне неврологічне захворювання, від якого страждають молоді люди, яке спричиняє численні терапевтичні проблеми і призводить до тяжкої інвалідизації. Глатирамер ацетат (ГА) є одним із препаратів, що модифікують захворювання, і використовується часто для впливають на захворювання; він часто використовується для лікування пацієнтів із такою патологією. Ми досліджували вплив лікування із застосуванням ГА на параметри зорових ВП, які виникали після пред'явлення реверсивного патерну, та пов'язаного з подією потенціалу Р300 (що відбивають гостроту зору та когнітивну дисфункцію відповідно). Пацієнти, які страждали від розсіяного склерозу (ті, що пройшли однорічний безперервний лікувальний курс із застосуванням ГА, та ті, що не піддавалися такій терапії, модифікуючій захворювання), і здорові суб'єкти (контроль) брали участь у дослідженні. Згадані параметри аналізували у двох моментах часу - при першій реєстрації та через рік. Виявлено, що ГА не демонстрував істотних ефектів щодо параметрів, що вивчалися, в усякому разі в межах одного року. Цей факт суперечить багатьом описаним клінічним спостереженням.

\section{REFERENCES}

1. C. H. Polman, S. C. Reingold, B. Banwell, et al., "Diagnostic criteria for multiple sclerosis: 2012 revisions to the McDonald criteria," Ann. Neurol., 69, No. 2, 292-302 (2011).

2. I. P. Chatziralli, M. M. Moschos, D. Brouzas, et al., "Evaluation of retinal nerve fiber layer thickness and visual evoked potentials in optic neuritis associated with multiple sclerosis," Clin. Exp. Optom., 95, No. 2, 223-228 (2012).

3. B. Weinstock-Guttman, M. Baier, R. Stockton, et al., "Pattern reversal visual evoked potentials as a measure of visual pathway pathology in multiple sclerosis," Mult. Scler., 9, No. 5, 529-534 (2003).

4. R. M. Liscic and J. Brecelj, "Visual evoked potentials in multiple sclerosis patients treated with interferon beta-1a," Croat. Med. J., 45, No. 3, 323-327 (2004).

5. O. Anlar, M. Kisli, T. Tombul, et al., "Visual evoked potentials in multiple sclerosis before and after two years of interferon therapy," Int. J. Neurosci., 113, No. 4, 483-489 (2003).

6. S. G. Meuth, S. Bittner, C. Seiler, et al., "Natalizumab restores evoked potential abnormalities in patients with relapsingremitting multiple sclerosis," Mult. Scler., 17, No. 2,198-203 (2011).

7. J. W. Chan, "Early diagnosis, monitoring, and treatment of optic neuritis," Neurologist, 18, No. 1, 23-31 (2012).

8. M. R. Newton, G. Barrett, M. M. Callanan, et al., "Cognitive event-related potentials in multiple sclerosis," Brain, 112, No. 6, 1637-1660 (1989).

9. J. Polich and J. R. Criado, "Neuropsychology and neuropharmacology of $\mathrm{P} 3 \mathrm{a}$ and P3b," Int. J. Psychophysiol., 60, No. 2, 172-185 (2006).
10. J. C. Aminoff and D. S. Goodin, "Long-latency cerebral eventrelated potentials in multiple sclerosis," J. Clin. Neurophysiol., 18, 372-377 (2001).

11. M. R. Piras, I. Magnano, E. D. G. Canu, et al., "Longitudinal study of cognitive dysfunction in multiple sclerosis: neuropsychological, neuroradiological and neurophysiological findings," J. Neurol. Neurosurg. Psychiat., 74, 878-885 (2003).

12. I. Magnano, I. Aiello, and M. R. Piras, "Cognitive impairment and neurological correlates in multiple sclerosis," J. Neurol. Sci., 245, 117-122 (2006).

13. R. J. J. Gonzales, M. Vasquez, E. Vaquero, et al., "Differential cognitive impairment for diverse forms of multiple sclerosis," BMC Neurosci., 19, 7-39 (2006).

14. G. Nagels, M. B. D'hooghe, L. Vleugels, et al., "P300 and treatment effect of modafinil on fatigue in multiple sclerosis," J. Clin. Neurosci., 14, No. 1, 33-40 (2007).

15. S. Lori, E. Portaccio, V. Zipoli, et al., "Cognitive impairment and event-related potentials in pediatric multiple sclerosis: 2-year study," Neurol. Sci., 32, No. 6, 1043-1046 (2011).

16. S. Flechter, J. Vardi, Y. Finkelstein, et al., "Cognitive dysfunction evaluation in multiple sclerosis patients treated with interferon beta-1b: an open-label prospective 1 year study," Isr. Med. Assoc. J., 9, No. 6, 457-459 (2007).

17. P. Vogel, Kursbuch Klinische Neurophysiologie EMG-ENGEvozierte Potenziale, Thieme, Stuttgart (2006).

18. S. P. Koch, S. Koendgen, R. Bourayou, et al., "Individual alpha frequency correlates with amplitude of visual evoked potential and hemodynamic response," Neuroimage, 41, No. 2, 233-242 (2008).

19. D. Pojda-Wilczek, "Retrospective analysis of pattern VEP results in different ocular and systemic diseases," Klin. Oczna, 112, Nos. 7/9, 205-209 (2010).

20. R. T. Rousseff, P. Tzvetanov, and M. A. Rousseva, "The bifid visual evoked potential-normal variant or a sign of demyelination?" Clin. Neurol. Neurosurg., 107, No. 2, 113-116 (2005)

21. T. R. Marra, "The clinical significance of the bifid or 'W' pattern reversal visual evoked potential," Clin. Electroencephalogr., 21, No. 3, 162-167 (1990).

22. W. G. Sannita, S. Carozzo, M. Fioretto, et al., "Abnormal waveform of the human pattern VEP: contribution from gamma oscillatory components," Invest. Ophthalmol. Vis. Sci., 48, No. 10, 4534-4541 (2007).

23. J. M. Olichney, J. C.Yang, J. Taylor, et al., "Cognitive eventrelated potentials: biomarkers of synaptic dysfunction across the stages of Alzheimer's disease," J. Alzheimer's Dis., 26, Suppl. 3, 215-228 (2011).

24. Z. Z. Major, "Combined evoked potentials in co-occurring attention deficit hyperactivity disorder and epilepsy," Ideggyogy. Sz., 64, Nos. 7/8, 248-256 (2011).

25. M. Kipp, M. Victor, G. Martino, et al., "Endogenous remyelination: findings in human studies," CNS Neurol. Disord. Drug. Targets, 11, No. 5, 598-609 (2012).

26. L. I. Reicker, T. N. Tombaugh, L. Walker, et al., "Reaction time: An alternative method for assessing the effects of multiple sclerosis on information processing speed," Arch. Clin. Neuropsychol., 22, No. 5, 655-664 (2007). 